\title{
Formulation Design of Hydrocortisone Films for the Treatment of Aphthous Ulcers
}

\author{
Aftöz Ülser Tedavisi için Hidrokortizon Filmlerin Formülasyon Tasarımı
}

\author{
(D) Mohammed Gulzar AHMED*, (D) Sanjana ADINARAYANA \\ Yenepoya Pharmacy College and Research Centre, Department of Pharmaceutics, Mangalore, India
}

\begin{abstract}
Objectives: Research and development in oral drug delivery has evolved to the changeover of solid dosage forms from tablets to oral films. These films offer an elegant route for systemic drug delivery, with an advantage for patients who are suffering from difficulty in swallowing larger oral dosage forms. Aphthous ulcers are the most common oral lesions and are round or oval, with a grayish yellow, crateriform base. For the treatment of aphthous ulcers various marketed product are available, such as vitamin B12 tablets, benzydamine hydrochloride mouthwash or spray, steroid lozenges, and local anesthetics. Hence hydrocortisone is selected as the drug of choice for the treatment of aphthous ulcers, exhibiting antiinflammatory and immunosuppressant properties that inhibit the clinical manifestations. The main aim of the present study was to develop a hydrocortisone film in order to improve the therapeutic efficacy and bioavailability of hydrocortisone for the treatment of aphthous ulcers.

Materials and Methods: The hydrocortisone film was developed containing various concentrations of methylcellulose and propylene glycol (1.0$2.0 \% \mathrm{w} / \mathrm{v}$ ) by solvent casting. The prepared films were evaluated for various characterization studies like film forming capacity, visual appearance, thickness, weight variation, folding endurance, surface $\mathrm{pH}$, drug content, disintegration time, tensile strength, in vitro release study, ex vivo study, and stability studies.

Results: A total of five formulations were developed, out of which formulation F2 $(1.25 \% \mathrm{w} / \mathrm{v})$ is considered the optimized formulation as it showed the best results with respect to all characterization studies. A disintegration time of $44 \mathrm{~s}$ and maximum in vitro drug release, i.e. $97.55 \%$, were observed. Further, no significant changes were observed during stability studies for the optimized formulation.

Conclusion: Hydrocortisone oral films can be formulated as a potentially useful tool for effective treatment of aphthous ulcers with improved bioavailability, rapid onset of action, and increased patient compliance.
\end{abstract}

Key words: Aphthous ulcers, hydrocortisone, oral films, solvent casting method, tensile strength, ex vivo study

Öz

Amaç: Oral ilaç salımında araştırma ve geliştirme, katı dozaj formlarının tabletlerden oral filmlere geçişine doğru gelişmiştir. Bu filmler, daha büyük oral dozaj formlarını yutmakta zorluk çeken hastalar için sistemik ilaç salımında avantaj sağlayan, çok iyi bir yol sunar. Aftöz ülserleri en sık görülen yuvarlak veya oval, krater formunda bir tabanı olan grimsi sarı oral lezyonlardır. Aftöz ülserlerin tedavisi için B12 vitamini tabletleri, benzidamin hidroklorür gargarası veya spreyi, steroid pastiller ve lokal anestezikler gibi çeşitli ticari ürünler mevcuttur. Bu nedenle hidrokortizon, klinik belirtileri engelleyen anti-enflamatuvar ve immünsüpresif özellikler sergileyen aftöz ülserlerin tedavisi için tercih edilen etken madde olarak seçilmiştir. Bu çalışmanın temel amacı, aftöz ülserlerin tedavisinde hidrokortizonun terapötik etkinliğini ve biyoyararlanımını artırmak için hidrokortizon filmi geliştirmektir.

Gereç ve Yöntemler: Çözücü dökümüyle çeșitli konsantrasyonlarda metilselüloz ve propilen glikol (1.0-2.0\% w/v) içeren hidrokortizon filmi geliştirilmiştir. Hazırlanan filmler, film oluşturma kapasitesi, görsel görünüm, kalınlık, ağırlık değişimi, katlanma dayanıklılı̆ı, yüzey pH'ı, etken madde içeriği, dağılma süresi, gerilme direnci, in vitro salım çalışması, ex vivo çalışma ve stabilite çalışmaları gibi çeşitli karakterizasyon çalışmaları için değerlendirilmiştir.

Sonuçlar: Toplam beş formülasyon geliștirilmiştir; bunlardan F2 formülasyonu (\%1.25 a/h), tüm karakterizasyon çalıșmalarına göre en iyi sonuçları gösterdiği için optimize edilmiş formülasyon olarak kabul edilmiștir. 44 s'lik bir dağılma süresi ve maksimum in vitro etken madde salımı, yani \%97.55, gözlenmiştir. Ayrıca, optimize edilmiş formülasyon için stabilite çalışmaları sırasında önemli bir değişiklik gözlenmemiștir.

Bulgular: Hidrokortizon oral filmler, gelişmiş biyoyararlanım, hızlı etki başlangıcı ve artan hasta uyumu ile aftöz ülserlerin etkili tedavisi için potansiyel olarak faydalı bir araç olarak formüle edilebilmiştir

Anahtar kelimeler: Aftöz ülserler, hidrokortizon, oral filmler, çözücü döküm yöntemi, çekme dayanımı, ex vivo çalışma

*Correspondence: E-mail: mohammedgulzar1@gmail.com, Phone: +09448401238 ORCID-ID: orcid.org/0000-0002-9226-9984

Received: 08.03.2018, Accepted: 21.06.2018

๑Turk J Pharm Sci, Published by Galenos Publishing House. 


\section{INTRODUCTION}

Over the past few decades there has been a tremendous change in the design of various drug delivery systems to achieve rapid onset of action. Travelling through the various milestones from discovering a conventional tablet, capsules, and modified release tablets and capsules, oral disintegrating tablets/wafers to achieve oral drug administration were quite popular. Now another potential milestone in the novel era of formulating films, ${ }^{1}$ mouth dissolving films are novel dosage forms that disintegrate or dissolve in the oral cavity. These are ultrathin postage stamp size formulations with an active agent or pharmaceutical excipients. These dosage forms are placed on the tongue or any mucosal tissue. When wet with saliva, the films rapidly hydrate and adhere to the site of application. They rapidly dissolve or disintegrate to release the drug for mucosal absorption or with modification allow for oral gastrointestinal tract absorption with quick dissolving properties. An important benefit of these dosage forms is accurate dosing as compared to liquid dosage form. ${ }^{2}$ Films are the most advanced form of oral solid dosage forms since they improve the efficacy of APIs by dissolving within a minute in the oral cavity after contact with less saliva as compared to fast dissolving tablets, without chewing and with no need for water for administration.' They give quick absorption and instant bioavailability of drugs due to high blood flow and permeability of the oral mucosa, which is 4-1000 times greater than that of the skin. ${ }^{3}$

Aphthous ulcers belong to the group of chronic inflammatory diseases of the oral mucosa. The most characteristic symptom of the disease is the recurrent onset of single or multiple painful erosions and ulcers that appear mainly on unattached oral mucosa of the lips, cheeks, and tongue. Occasionally the lesions may also be observed on strongly keratinized palatal and gingival mucosa. The eruptions are surrounded by a characteristic erythematous halo and covered with a fibrous coating.

Aphthous ulcers are classified as minor, major, and herpetiform. Minor aphthous ulcers involve the presence of one to five ulcers at a time, with each ulcer less than $1 \mathrm{~cm}$ in diameter. In major aphthous ulcers there are 1-10 ulcers at a time, the ulcers exceed $1 \mathrm{~cm}$ in diameter, and they persist for up to 6 weeks. In herpetiform recurrent aphthous ulcers there are 10-100 ulcers at a time, their size is usually $1-3 \mathrm{~cm}$, and they form clusters that coalesce into widespread areas of ulceration lasting 7-10 days. These ulcers are only herpes-like in appearance. ${ }^{4}$
Corticosteroids are a class of drugs that includes steroid hormones. Topical corticosteroid when used for aphthous ulcers is intended to limit the inflammatory process associated with the formation of aphthae. Corticosteroids may act directly on $T$ lymphocytes or alter the response of effector cells to precipitants of immunopathogenesis. Hydrocortisone is a corticosteroid with both glucocorticoid and to a lesser extent mineralocorticoid activity. It exhibits anti-inflammatory and immunosuppressant properties inhibiting the clinical manifestations. ${ }^{5}$ It is chemically designated as pregn-4-ene3,20-dione,21 (acetyloxy)-11,17-dihydroxy-, (11ß)-. It is a white to partially white, odorless, crystalline powder that is well absorbed after oral administration, achieving peak blood concentrations after $1 \mathrm{~h}$. Plasma protein binding is greater than $90 \%$, primarily bound to plasma globulin as globulins have a high affinity for hydrocortisone but low binding capacity. These pharmacokinetic parameters make hydrocortisone a suitable candidate for film formulation. ${ }^{6}$

Thus, the main objective of the present investigation was to formulate oral films containing hydrocortisone by solvent casting, which is simple and cost effective to minimize the first pass effect, increase the oral bioavailability, and provide rapid onset of action, thereby increasing patient compliance.

Although the research concerning local drug delivery for the treatment of aphthous ulcer has attracted much attention, there is greater potential in the treatment offered by local drug delivery, and research has proved this to be an alternative method of current conventional treatment.

\section{MATERIALS AND METHODS}

\section{Materials}

Hydrocortisone was procured from Yarrow Chem. Products, Mumbai. Methyl cellulose and sodium citrate were procured from SD Fine Chemicals, Mumbai. All other ingredients used were of analytical grade.

\section{Formulation method of mouth dissolving films}

Different composition formulas were optimized as a primary film former for the formulation (Table 1). Aqueous solution of methylcellulose was prepared by dissolving it in $50 \mathrm{~mL}$ of hot water with continuous stirring to form a homogeneous solution and then the solution was kept for swelling of the polymer. Propylene glycol and sodium citrate were dissolved in $10 \mathrm{~mL}$ of distilled water and the drug was also separately dissolved

\section{Table 1. Formulation design of oral film}

\begin{tabular}{llllll} 
Formulation code & Hydrocortisone $(\% w / v)$ & Methylcellulose $(\% w / v)$ & Sodium citrate $(\% w / v)$ & Propylene glycol & Distilled water \\
\hline F1 & 1 & 1.00 & 0.25 & 1.00 & Q.S \\
\hline F2 & 1 & 1.25 & 0.25 & 1.25 & Q.S \\
\hline F3 & 1 & 1.50 & 0.25 & 1.50 & Q.S \\
\hline F4 & 1 & 1.75 & 0.25 & 1.75 & Q.S \\
\hline F5 & 1 & 2.00 & 0.25 & 2.00 & Q.S \\
\hline
\end{tabular}


in distilled water to form a solution. Both of these solutions were mixed in a polymer solution with continuous stirring and kept for $2 \mathrm{~h}$ for removal of the air bubbles. Then the prepared solutions were cast onto moulds and kept in air for drying and then in a hot air oven for $24 \mathrm{~h}$ at $40^{\circ} \mathrm{C}$. Finally, the films were removed from the mould and cut to $0.5 \mathrm{~cm} \times 0.5 \mathrm{~cm}$ size. ${ }^{7}$

\section{Evaluation parameters for films}

\section{Fourier transform infrared studies}

The compatibility of the drug in the formulation was confirmed by IR spectra of pure drug alone and the formulations were determined using a Shimadzu fourier transform infrared (FTIR)$8400 \mathrm{~S}$ spectrophotometer by the $\mathrm{KBr}$ disc method. ${ }^{7}$

\section{Scanning electron microscopy}

The morphology and surface topography of the film were examined by scanning electron microscopy (SEM). The samples to be examined were mounted on a SEM sample stub using double-sided adhesive tape. The samples mounted were coated with gold (200 $\AA$ ) under reduced pressure ( 0.001 torr) for 5 min to improve the conductivity using an ion sputtering device. ${ }^{8}$

\section{Differential scanning calorimetry}

Thermal properties of the pure drug and the formulation were evaluated by differential scanning calorimetry (DSC). It is used to determine drug excipient compatibility studies and also used to observe more phase changes, such as glass transitions, crystallization, and amorphous forms of drugs and polymers. The analysis was performed at 5 to $200^{\circ} \mathrm{C}$ under nitrogen flow. ${ }^{8}$

\section{Thickness}

Film thickness was evaluated using a screw gauge with a range of $0-10 \mathrm{~mm}$ and revolution $0.001 \mathrm{~mm}$. The anvil of the thickness gauge was turned and the film was inserted after making sure that the pointer was set to zero. The film was held on the anvil and the reading on the dial was noted down. The estimations were carried out in triplicate. ${ }^{?}$

\section{Variation in mass}

The mass of $0.5 \mathrm{~cm}^{2}$ film from different batches of the formulations was noted on an electronic balance. The estimations were carried out in triplicate. ${ }^{9}$

\section{Folding endurance}

Folding endurance was determined by repeated folding of the film at the same place until the film broke. This gives an indication of the brittleness of the film. The number of times the film was folded without breaking was computed as the folding endurance value. The estimations were carried out in triplicate. ${ }^{8}$

\section{Surface $\mathrm{pH}$}

The surface $\mathrm{pH}$ of the film is determined in order to investigate the possibility of any irritation in vivo. As an acidic or alkaline $\mathrm{pH}$ may cause irritation to the oral mucosa, it is necessary to keep the surface $\mathrm{pH}$ as close to neutral as possible. A combined $\mathrm{pH}$ electrode was used for this purpose. The film was slightly wet with the help of water and the $\mathrm{pH}$ was measured by bringing the electrode in contact with the surface of the oral film. This study was performed in triplicate and mean \pm standard deviation calculated. ${ }^{10}$

\section{Drug content}

Film of $0.5 \mathrm{~cm}^{2}$ size was put in a $10 \mathrm{~mL}$ volumetric flask and dissolved in $5 \mathrm{~mL}$ of methanol and then the final volume was made up with methanol. Samples were suitably diluted with artificial saliva and the absorbance was measured at $242 \mathrm{~nm}$. The estimations were carried out in triplicate..$^{10}$

\section{In vitro disintegration studies}

Disintegration time gives an indication about the disintegration characteristics and dissolution characteristics of the film. In the case of films the disintegration and dissolution procedures are hardly distinguishable. If the film disintegrates it concurrently dissolves in a small amount of saliva, which makes it difficult to mimic these natural conditions and measures with an adequate method. However, in the present investigation two methods of disintegration were adopted. ${ }^{8}$

Drop method: In the first method one drop of distilled water was dropped by a pipette onto the oral films. The films were placed on a glass slide and then the glass slide was placed planar on a petri dish. The time until the film dissolved and caused a hole in the film was measured. The estimations were carried out in triplicate.

Petri dish method: In this method $2 \mathrm{~mL}$ of distilled water was placed in a petri dish and one film was added to the surface of the water and the time required until the oral film dissolved completely was measured. Drug-loaded films were investigated under both methods. The estimations were carried out in triplicate.

\section{Tensile strength}

Tensile strength is the maximum stress applied to a point at which the film specimen breaks. It is calculated by the load at rupture divided by the cross-sectional area of the film as given below:

Tensile strength $=\frac{\text { Force at break }(\mathrm{N})}{\text { Initial cross-sectional area of the sample }\left(\mathrm{mm}^{2}\right)}$

It was measured using a Shimadzu AG-100kNG (Winsoft tensile and compression testing). Film of size $5 \times 5 \mathrm{~cm}^{2}$ and free of physical imperfections was placed between two clamps held 10 $\mathrm{mm}$ apart. The film was pulled by a clamp at a rate of $5 \mathrm{~mm} / \mathrm{min}$. The whole experiment was carried out in triplicate. ${ }^{9}$

\section{In vitro dissolution studies}

The in vitro dissolution studies were conducted using $500 \mathrm{~mL}$ of artificial saliva as dissolution medium with a modified type I dissolution apparatus. A temperature of $37^{\circ} \mathrm{C}$ and speed of 50 rpm were used. Each film with dimensions of appropriate size equivalent to $5 \mathrm{mg}$ of hydrocortisone was placed on a watch glass covered with nylon wire mesh. The watch glass was then dropped into a dissolution flask (Figure 1). Then 5-mL samples were withdrawn after 1, 2, 3, 4, 5, 6, 7, and $8 \mathrm{~h}$ and every time replaced with $5 \mathrm{~mL}$ of fresh dissolution medium. The samples were analyzed by measuring absorbance at $242 \mathrm{~nm}$. The dissolution experiments were conducted in triplicate. ${ }^{7}$ 


\section{Ex vivo diffusion studies}

An ex vivo release study was conducted using fresh chicken skin. The skin was soaked in sodium bromide solution for $5-6 \mathrm{~h}$ and washed with water to remove the adhering fat tissue. Then the skin was mounted in a diffusion cell containing phosphate buffer of $\mathrm{pH}$ 6.8. The temperature of the medium was thermostatically controlled at $37 \pm 1.0^{\circ} \mathrm{C}$ and $5 \mathrm{~mL}$ of the sample was withdrawn at predetermined intervals and spectrophotometrically estimated at $242 \mathrm{~nm}$ against the respective blank formulation. ${ }^{10}$

\section{Drug release kinetics}

Investigation of the drug release from the films was done by studying the release data with zero order and first order kinetics and the Higuchi equation. The release mechanism was understood by fitting the data to the Korsmeyer-Peppas model. ${ }^{9}$

\section{Stability study}

The stability study for the oral films was carried out for all the batches for a short-term period of 3 months. After predetermined time intervals, the films were evaluated for drug content, $\mathrm{pH}$, thickness, disintegration study, and physical appearance. $^{10}$

\section{RESULTS AND DISCUSSION}

\section{FTIR studies}

The infrared spectra of the pure drug hydrocortisone and combinations of the drug with polymers (methylcellulose) were obtained and are shown in figures. All the characteristic peaks of hydrocortisone were present in the spectrum of the drug and polymer mixture, indicating compatibility between drug and polymer. The spectrum confirmed that there is no significant change in the chemical integrity of the drug and the formulation and it is shown in Figure 2.

\section{SEM analysis}

Macroscopically the prepared hydrocortisone films were clear. The scanning electron photomicrographs of the selected films at 400x magnification are shown in Figure 3. The SEM photographs of the films showed smooth surfaces without any scratches or transverse striations, indicating that hydrocortisone is uniformly distributed and no crystals of hydrocortisone were observed in the films.

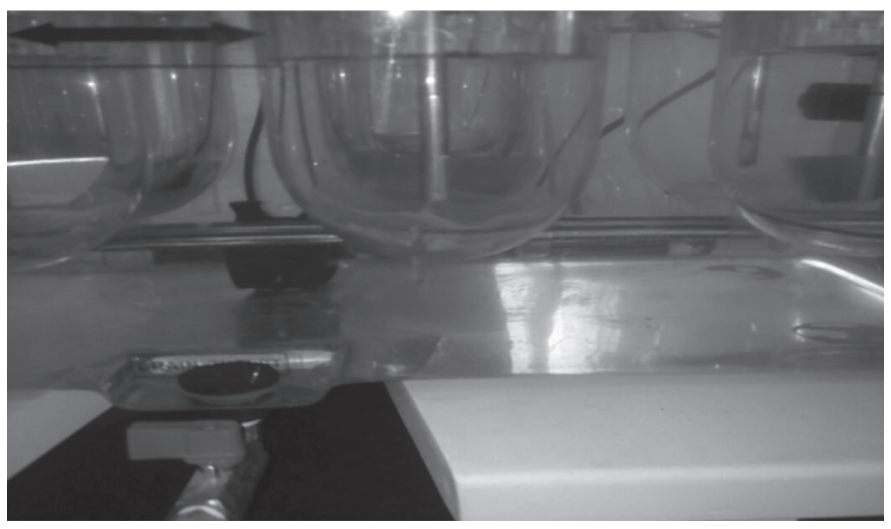

Figure 1. Drug release profile of the formulations

\section{DSC study}

The DSC study of the pure drug showed a sharp endothermic peak at $220.26^{\circ} \mathrm{C}$. Similar endothermic peaks were obtained in the formulations at $202.62^{\circ} \mathrm{C}$, clearly indicating that there was no drug-polymer interaction. The results of the DSC thermogram are shown in Figure 4.

\section{Thickness of the films}

Thickness was measured with a screw gauge at different places of the film in order to evaluate the reproducibility of the preparation method. The thickness was in the range of $470 \pm 0.09$ to $490 \pm 0.03 \mu \mathrm{m}$. Around $90 \%$ of wet film thickness was lost during drying. The results are given in Table 2. For the prepared film a good uniformity of thickness was observed.

\section{Weight variation of the films}

Films of $0.5 \mathrm{~cm}^{2}$ were cut from different batches and weighed. The weights of different formulations were in the range of 0.0098 to $0.0100 \mathrm{~g}$ and the results are given in Table 2. The same mass of film was obtained with three batches of films, indicating reproducibility of the preparation method and formulation.

\section{Folding endurance}

All the prepared films have an acceptable folding endurance. The folding endurance test was in the range of 122 to 146 folds and no films developed any visible cracks or breaks, thus showing good folding endurance. Among the five different formulations, F5 has the highest folding endurance due to the presence of a higher concentration of methylcellulose $(2.00 \% \mathrm{w} / \mathrm{v})$ when compared with the other films. The results are shown in Table 2.

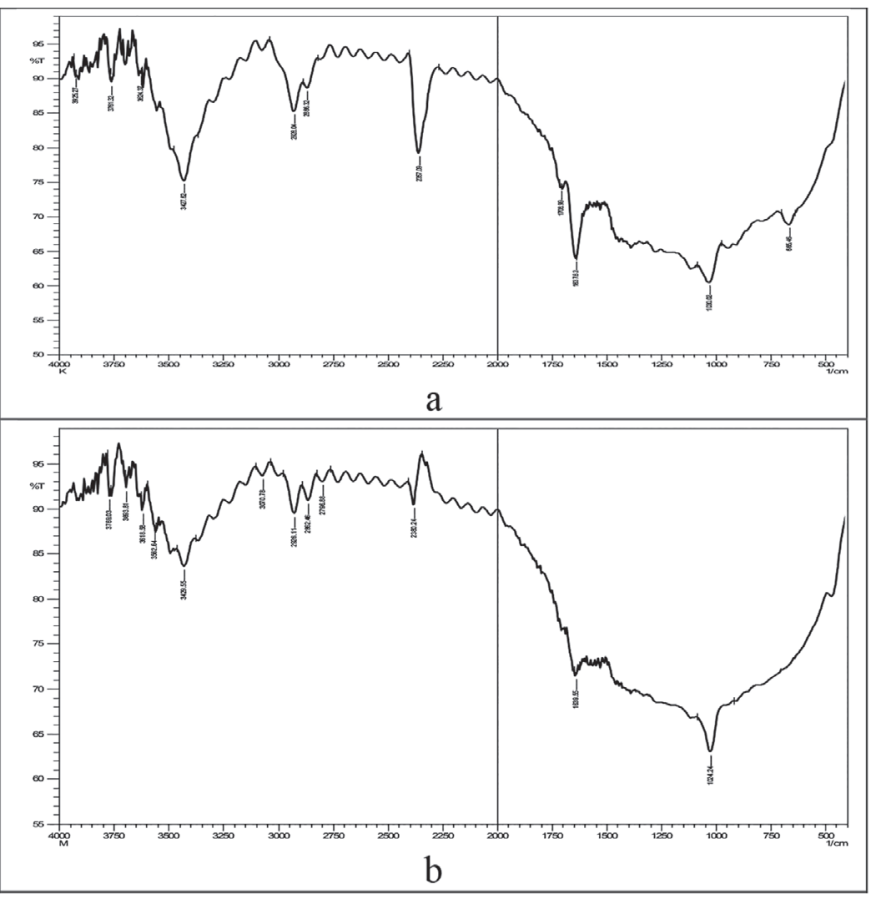

Figure 2. (a) FTIR of pure drug, (b) FTIR of drug with polymer FTIR: Fourier transform infrared 


\section{Surface $\mathrm{pH}$ of the films}

The surface $\mathrm{pH}$ of all films was in the range of $6.37 \pm 0.08$ to $6.79 \pm 0.01$. This assured that there will not be any kind of irritation to the mucosal lining of the oral cavity and the results are tabulated in Table 2.

\section{Disintegration time}

The disintegration time was in the range of 40 to $55 \mathrm{~s}$ in the drop method, whereas in the petri dish method it was e in the range of 43 to $56 \mathrm{~s}$ as shown in Table 2. These results indicated
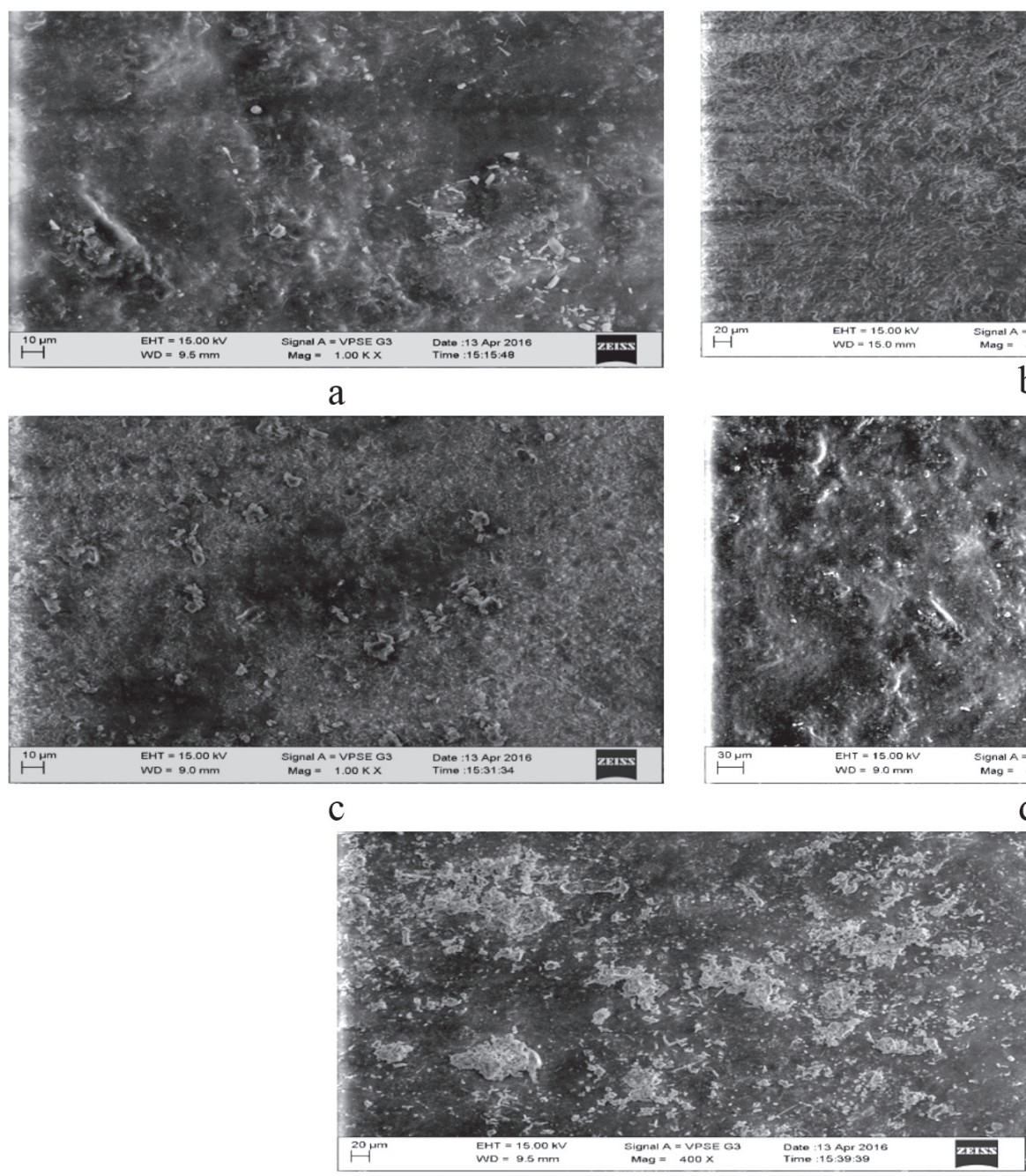

e that the formulation F1 disintegrated faster than the other formulations in the drop method. With the petri dish method F1, F2, and F3 disintegrated/dissolved faster than the other formulations.

\section{Drug content}

Films of $0.5 \mathrm{~cm}^{2}$ were cut from different places of the whole films for the estimation of drug content. The results were in the range of $95.6 \%$ to $98.4 \%$ as given in Table 3 . These results

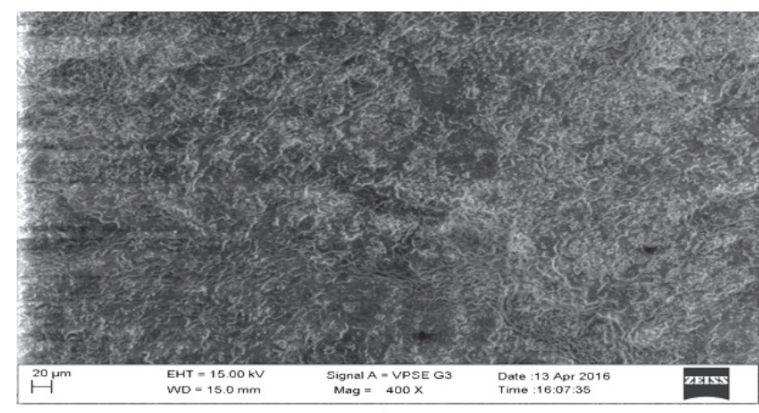

b

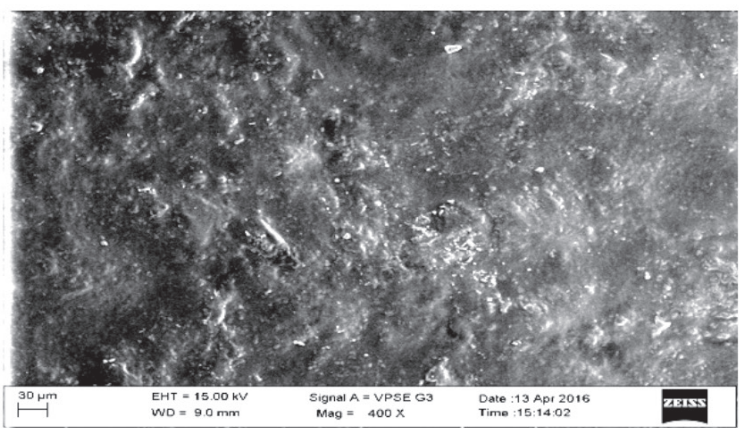

d

Figure 3. a. SEM of formulation (F1), b. SEM of formulation, (F2) c. SEM of formulation, (F3) d. SEM of formulation, (F4) E. SEM of formulation (F5) SEM: Scanning electron microscopy

\begin{tabular}{|c|c|c|c|c|c|c|}
\hline \multirow[t]{2}{*}{ Formulation code } & \multirow[t]{2}{*}{ Variation in mass $(\mathrm{g})$} & \multirow[t]{2}{*}{ Thickness $(\mu \mathrm{m})$} & \multirow[t]{2}{*}{ Surface $\mathrm{pH}$} & \multicolumn{2}{|c|}{ Disintegration time (s) } & \multirow{2}{*}{$\begin{array}{l}\text { Folding } \\
\text { endurance }\end{array}$} \\
\hline & & & & Drop method & Petri dish method & \\
\hline $\mathrm{F} 2$ & $0.0100 \pm 0.0007$ & $490 \pm 0.03$ & $6.79 \pm 0.024$ & $44 \pm 1.27$ & $480 \pm 2.56$ & 130 \\
\hline F3 & $0.0094 \pm 0.0006$ & $475 \pm 0.07$ & $6.55 \pm 0.022$ & $47 \pm 0.55$ & $520 \pm 1.32$ & 134 \\
\hline F5 & $0.0097 \pm 0.0005$ & $480 \pm 2.04$ & $6.49 \pm 0.019$ & $55 \pm 1.32$ & $568 \pm 2.54$ & 146 \\
\hline
\end{tabular}




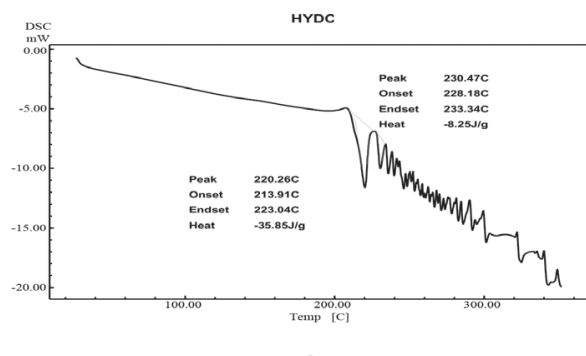

a

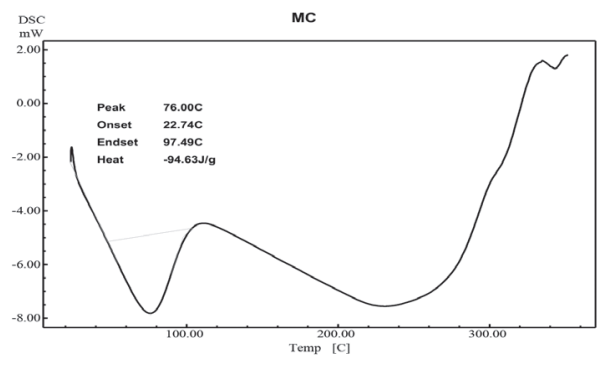

b
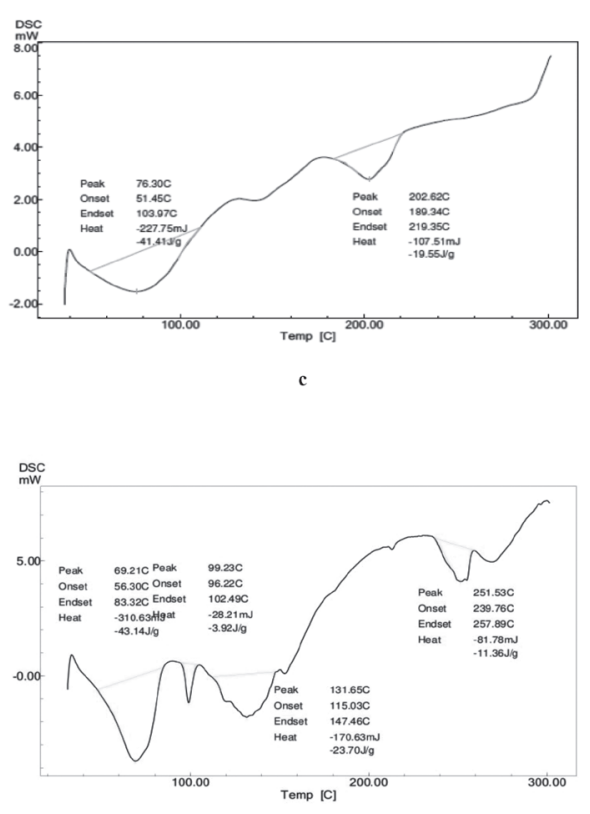

d
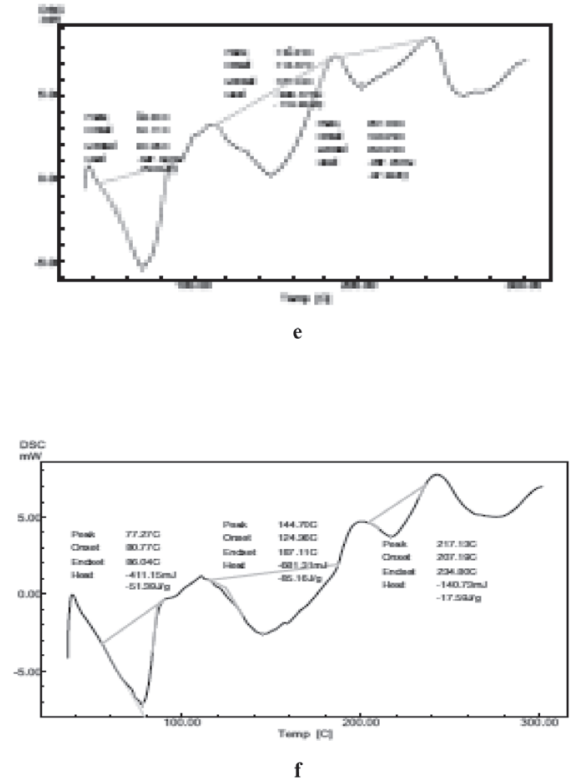

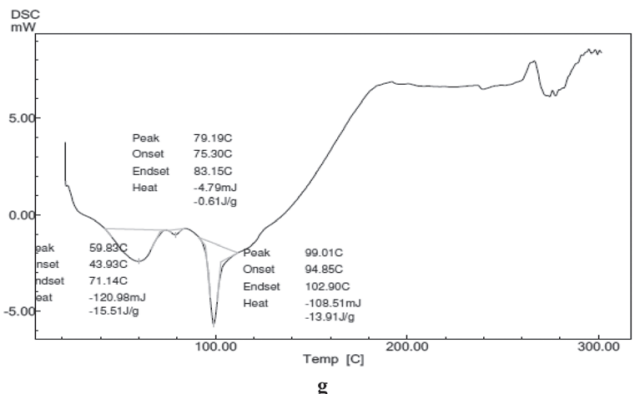

Figure 4. (a) DSC of pure drug, (b) DSC of polymer, (c) DSC of formulation (F1), (d) DSC of formulation (F2), (e) DSC of formulation (F3), (f) DSC of formulation (F4), (g) DSC of formulation (F5)

DSC: Differential scanning calorimetry

indicated a good uniformity of hydrocortisone within the films, and overall good solubilization of hydrocortisone in the formulations was observed.

\section{Tensile strength}

Films should possess moderate tensile strength, high \% elongation (E), and high percentage of drug release. The results revealed that all the films showed moderate tensile strength values ranging from 0.614 to $0.872\left(\mathrm{~kg} / \mathrm{mm}^{2}\right)$. Among all the formulations, F2 showed the highest \% $\mathrm{E}$ and tensile strength. The nature and concentration of the polymer affect the tensile strength and \% elongation. F2, having the optimum concentration of methylcellulose $(1.25 \%)$, showed the highest $\%$ of tensile strength and \% elongation. The results are given in Table 3.

\section{In vitro dissolution studies}

The hydrocortisone films were prepared using methylcellulose as film-forming polymer with sodium citrate. The in vitro

\section{Table 3. Tensile strength and elongation strength}

\begin{tabular}{llll} 
Batch code & $\begin{array}{l}\text { Tensile strength } \\
\left(\mathrm{kg} / \mathrm{mm}^{2}\right)\end{array}$ & Elongation (\%) & Drug content (\%) \\
\hline F1 & $0.614 \pm 0.034$ & $6.67 \pm 0.071$ & 95.6 \\
\hline F2 & $0.872 \pm 0.044$ & $7.67 \pm 0.005$ & 98.4 \\
\hline F3 & $0.72 \pm 0.072$ & $6.1 \pm 0.008$ & 96.0 \\
\hline F4 & $0.863 \pm 0.008$ & $6.01 \pm 0.072$ & 97.6 \\
\hline F5 & $0.75 \pm 0.023$ & $5.52 \pm 0.003$ & 96.8 \\
\hline
\end{tabular}

dissolution profiles of the hydrocortisone films were performed for all the different formulations and are shown in Figure 5. The cumulative percent of released hydrocortisone increased to the end of $8 \mathrm{~h}$. The release rate from different films shows that the release of drug increased with an increase in the concentration of the release retardant polymer at a certain level, i.e. $1.25 \%$, and a further increase in the concentration of the polymer decreased the release behavior of the formulation significantly. 
Table 4. Release exponent values and rate constant values for different formulations

\begin{tabular}{llllll}
\multirow{2}{*}{$\begin{array}{l}\text { Formulation } \\
\text { code }\end{array}$} & \multicolumn{2}{l}{ Kinetic models } \\
\cline { 2 - 6 } & Zero order & First order & Higuchi & \multicolumn{2}{l}{ Korsmeyer-Peppas } \\
\cline { 2 - 6 } & $\mathrm{R}^{2}$ & $\mathrm{R}^{2}$ & $\mathrm{R}^{2}$ & $\mathrm{R}^{2}$ & $\mathrm{n}$ \\
\hline $\mathrm{F} 1$ & 0.976 & 0.323 & 0.933 & 0.333 & 1.564 \\
\hline $\mathrm{F} 2$ & 0.977 & 0.596 & 0.818 & 0.713 & 1.835 \\
\hline F3 & 0.984 & 0.334 & 0.878 & 0.511 & 1.688 \\
\hline F4 & 0.998 & 0.317 & 0.904 & 0.440 & 1.613 \\
\hline F5 & 0.979 & 0.319 & 0.856 & 0.459 & 1.662
\end{tabular}

Table 5. Stability study

\begin{tabular}{lllll} 
& & \multicolumn{2}{l}{ Disintegration time (s) } & Drug \\
\cline { 3 - 4 } Formulation (F2) & Surface pH & $\begin{array}{l}\text { Drop } \\
\text { method }\end{array}$ & $\begin{array}{l}\text { Petri dish } \\
\text { method }\end{array}$ & \\
\hline Before & $6.79 \pm 0.024$ & $44 \pm 1.27$ & $480 \pm 2.56$ & 98.4 \\
\hline After & $6.74 \pm 0.015$ & $46 \pm 1.03$ & $460 \pm 1.22$ & 95.6 \\
\hline
\end{tabular}

\section{Release kinetics}

In order to determine the release kinetics, the data of the release profile were subjected to various kinetics models. The release exponent ' $n$ ' values of the Korsmeyer-Peppas model were from 1.564 to 1.853 , indicating the drug release pattern was a super case II mechanism. The data of the kinetics studies are shown in Table 4.

\section{Ex vivo studies}

Among the five different formulations the best formulation was subjected to an ex vivo release study through chicken skin using a diffusion cell. Ex vivo release would give a better estimate of drug permeation characteristics through animal skin. The amount of drug that permeated through the skin after $8 \mathrm{~h}$ from the formulation is shown in Figure 6.

\section{Stability study}

The selected optimized formulation F2 was subjected to short-term accelerated stability studies for 3 months at $25 \% 60 \%$ and $40 \% 75 \% \mathrm{RH}$. The samples were evaluated for any physical changes, disintegration rate, $\mathrm{pH}$, and drug content. No discernible change in the physical appearance was seen in the samples and the disintegration rate, $\mathrm{pH}$, and drug content values were found to be the same. The film was white, smooth, nonsticky, and flexible after the stability studies (Table 5).

\section{CONCLUSIONS}

The main objective of the study was to formulate and evaluate an oral film containing hydrocortisone. The films can be easily formulated by solvent casting using polymers such as methylcellulose in different ratios with a suitable plasticizer like propylene glycol. The compatibility of hydrocortisone with polymers was confirmed by FTIR, SEM, and DSC studies. It was observed that the physicochemical characteristics such as uniformity of weight, thickness, folding endurance, surface $\mathrm{pH}$, and uniformity of drug content of all the film samples
In-vitro release study

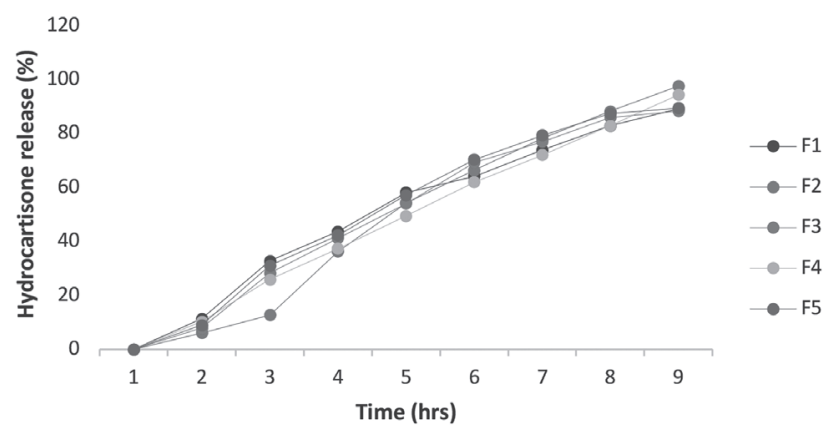

Figure 5. Comparative drug release profile of the formulations

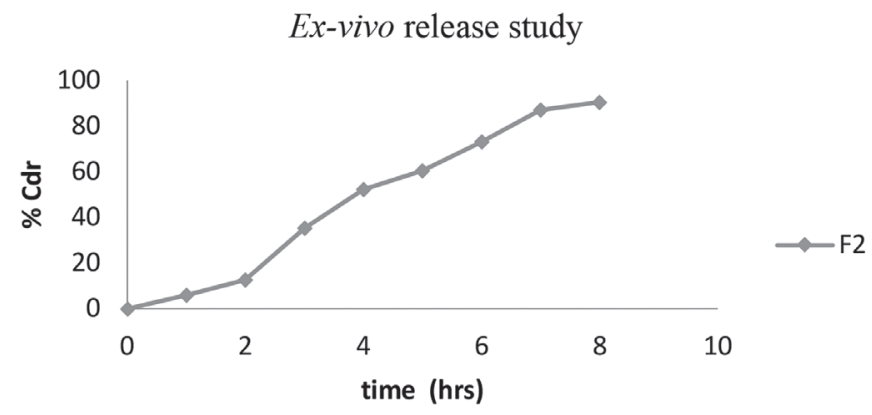

Figure 6. Ex vivo release studies

showed satisfactory results with respect to variation in these parameters between films of the same formulation. Tensile strength and percentage elongation of the films increased with an increase in the concentration of methylcellulose polymer. Disintegration time of the films was 40 to $55 \mathrm{~s}$. Based on the physicochemical parameters and in vitro drug release studies, formulations F2 and F4 were considered the best formulations, exhibiting drug release of $97.54 \%$ and $94.29 \%$, respectively, at the end of 8 h. Ex vivo drug release studies through chicken skin also showed similar results. The present study reveals that all five formulated films showed satisfactory film parameters. Out of these five formulations, F2 $(1.25 \% \mathrm{w} / \mathrm{v})$ showed better results when compared to the other formulations. From the present investigation it can be concluded that film formulation can be a potential novel drug dosage form for pediatric and geriatric populations and also for the general population.

\section{ACKNOWLEDGEMENT}

The authors are sincerely thankful to the principal of Sri Adichunchanagiri College of Pharmacy, B.G. Nagara, for providing us with the infrastructure facilities and moral support to carry out this research work.

Conflict of Interest: No conflict of interest was declared by the authors.

\section{REFERENCES}

1. Kumar RK, Sulochana MM. Formulation and evaluation of Fast dissolving films of Lercandipine Hydrochloride. IJIDD. 2014;4:46-53. 
2. Ketul P, Patel KR, Patel MR, Patel NM. Fast dissolving films: A Novel approach to oral drug dilivery. AJPST. 2013;3:25-31.

3. Vucicevic Boras V, Savage NW. Recurrent aphthous ulcerative disease: Presentation and management. Aust Dent J. 2007;52:10-15.

4. Barrons RW. Treatment strategies for recurrent oral aphthous ulcers. Am J Health Syst Pharm. 2001;58:41-50.

5. Grover NK, Babu R, Bedi SPS. Steroid therapy- current indications in practice. Ind J Anesth. 2007;51:389-393.

6. Gupta P, Bhatia V. Corticosteroid physiology and principal of therapy. Ind J Pediat. 2008:1039-1044.
7. Maheshwari KM, Devineni PK, Deekonda S. Development and evaluation of mouth dissolving films of Amlodipine besylate for enhanced therapeutic efficacy. Hindawi J Pharm. 2014:1-10.

8. Patidar MK, Karjikar FA, Patel FA, Rathi SS, Thokal SB, Bhingare CL. Formulation and evaluation of mouth dissolving films of zolpidem tartrate by exploration on polymers combination. Int J Pharm. 2013;3:716-721.

9. Aviral K, Prajapati SK. Formulation and evaluation of dental film for periodontaitis. IRJP. 2012;3:143-148.

10. Rani JL. Formulation and in vitro and in vivo evaluation of oral dispersable films of loronoxicam. Int J Sci Tec. 2014;24:1649-1655. 